\title{
Electrochemical Deoxidation of Titanium in Molten $\mathrm{MgCl}_{2}-\mathrm{HoCl}_{3}$
}

\author{
Lingxin Kong a , Takanari Ouchia, ${ }^{a}{ }^{,}$, Toru H. Okabe \\ anstitute of Industrial Science, The University of Tokyo, 4-6-1 Komaba, Meguro-ku, \\ Tokyo 153-8505, Japan \\ *t-ouchi@iis.u-tokyo.ac.jp
}

\begin{abstract}
$\underline{\text { Abstract }}$
A new electrochemical deoxidation method is proposed for $\mathrm{Ti}$, wherein a mixture of magnesium chloride and holmium chloride $\left(\mathrm{MgCl}_{2}-\mathrm{HoCl}_{3}\right)$ is used as a flux. In the new process, Ti and $\mathrm{C}$ are used as the cathode and anode, respectively. $\mathrm{Mg}$ is deposited on the Ti cathode, which reduces the $\mathrm{O}$ in Ti to oxide ions $\left(\mathrm{O}^{2-}\right)$. The activity of the generated $\mathrm{O}^{2-}\left(a_{\mathrm{O}^{2-}}\right)$ in the system was effectively maintained at a low level by the formation of holmium oxychloride (HoOCl) and further decreased by the electrochemical oxidation reaction on the anode. By applying a voltage of $3.0 \mathrm{~V}$ between the cathode and anode at $1173 \mathrm{~K}$, Ti was effectively deoxidized to approximately 1000 mass ppm O. Based on the results, in this study, an electrochemical cell, that simultaneously deoxidize Ti scrap or powders and recover HoOCl, is designed.
\end{abstract}

Keywords: Titanium scrap, Electrochemical deoxidation, Holmium, Molten salt

\section{$\underline{\text { 1. Introduction }}$}

The demand for $\mathrm{Ti}$ and its alloys has been increasing in various fields, particularly in the aerospace industry, due to their outstanding properties, such as corrosion resistance and high specific strength. In the aerospace industry, the volume of scrap generated is far greater than that of fabricated Ti products due to the high affinity of Ti for $\mathrm{O}^{[1]}$. Currently, $12 \mathrm{t}$ of Ti products are manufactured from 100 t of Ti ingots, while a large amount of Ti scrap is produced in the process (scrap, turning, etc. $)^{[2]}$.

Considering the high production cost of $\mathrm{Ti}$ and the increasing demand for $\mathrm{Ti}$ and its alloys, the recycling of Ti scrap has become an important issue. It is desirable to remelt scraps with virgin metals ( $\mathrm{Ti}$ sponge) to produce primary ingots of Ti or its alloys. However, the scrap is unsuitable as a feed material in the remelting process because $\mathrm{O}$ accumulates in the Ti ingots. Oxygen contamination of the product should be prevented because the presence of $\mathrm{O}$ deteriorates the performance of the metal ${ }^{[3]}$. Therefore, an effective process for directly removing $\mathrm{O}$ from Ti scraps is highly desired.

Metallic Ti has a strong binding affinity with $\mathrm{O}^{[4]}$. In addition, as shown in Fig. 1 , $\mathrm{O}$ is highly soluble in metallic $\mathrm{Ti}^{[5,6]}$. At $1173 \mathrm{~K}$, the solubility limit of $\mathrm{O}$ in $\beta$-Ti is approximately 0.2 mass $\%$, and in $\alpha$-Ti, the solubility of $\mathrm{O}$ is as high as 14 mass \%. Owing to these inherent properties, it is well known that deoxidation of metallic Ti is extremely difficult ${ }^{[7]}$. 


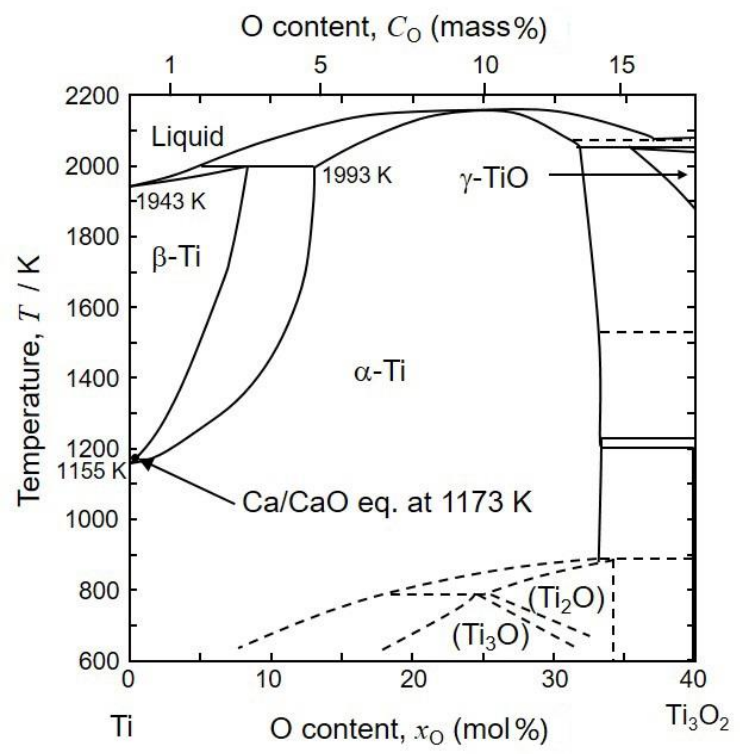

Fig. 1 Phase diagram of the Ti-O binary system ${ }^{[5,6]}$. Composition of $\mathrm{Ti}-\mathrm{O}$ solution under the $\mathrm{Ca} / \mathrm{CaO}$ equilibrium at $1173 \mathrm{~K}$ is plotted in the figure.

In the past, various techniques (e.g., solid-state electrotransport (SSE) and metal/metal oxide equilibrium) for the direct removal of $\mathrm{O}$ from $\mathrm{Ti}$ have been proposed and studied ${ }^{[8-13]}$. By employing some of these techniques, the $\mathrm{O}$ concentration in $\mathrm{Ti}$ can be reduced to 500 mass ppm $\mathrm{O}$ or less at the laboratory scale. However, none of these techniques has been industrialized at a large scale yet, due to their low efficiency.

Deoxidation of $\mathrm{Ti}$ using $\mathrm{Mg}$ as a deoxidant is generally believed to be impossible because of its weak deoxidation ability. The equilibrium $\mathrm{O}$ concentration under the $\mathrm{Mg} / \mathrm{MgO}$ equilibrium is approximately 1.9 mass\% at $1173 \mathrm{~K}{ }^{[14]}$. For reference, as shown in Fig. 1, the equilibrium $\mathrm{O}$ concentration of $\mathrm{Ti}$ under the $\mathrm{Ca} / \mathrm{CaO}$ equilibrium at $1173 \mathrm{~K}$ is plotted as a filled circle (approximately 0.03 mass $\%$ O) ${ }^{[14]}$. This shows that it is thermodynamically difficult to remove $\mathrm{O}$ directly from Ti to levels below 1 mass\% O by Mg deoxidation when the activity of $\operatorname{MgO}(s)\left(a_{\mathrm{MgO}(s)}\right)$ is high. However, if Ti can be deoxidized using $\mathrm{Mg}$ as the deoxidant in $\mathrm{MgCl}_{2}$ flux, the reduction and electrolysis facilities of the conventional $\mathrm{Kroll}$ process can be utilized, which would be advantageous in practical application. Furthermore, the surface structure of Ti scraps is often complex, so a large amount of salt is likely to remain attached to their surface after deoxidation. Hence, the removal of the attached salts using evaporation is necessary. Figure 2 shows the vapor pressures of some chlorides and $\mathrm{Mg}$ as a function of temperature ${ }^{[2,4]} \cdot \mathrm{MgCl}_{2}$ and $\mathrm{Mg}$ can be easily removed from metallic Ti by vacuum distillation because of their high vapor pressure. In effect, in the Kroll process, the most commonly used Ti smelting process, $\mathrm{MgCl}_{2}$ generated as a byproduct of the Ti-reduction step can be removed directly from the Ti sponge by evaporation ${ }^{[2]}$. 


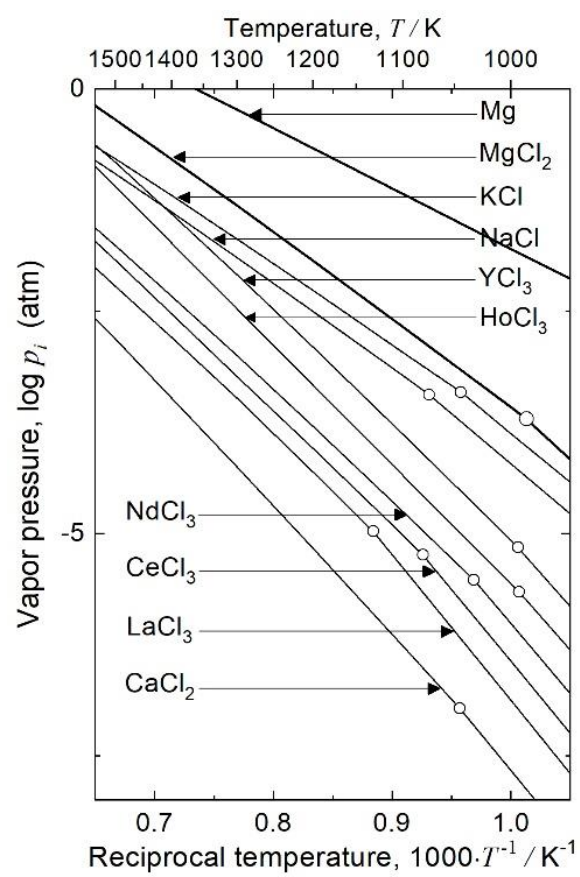

Fig. 2 Temperature dependence of vapor pressure of some chlorides and $\mathrm{Mg}[2,4]$.

To obtain $\mathrm{Ti}$ with a low oxygen concentration using metallic $\mathrm{Mg}$ as a deoxidant in molten $\mathrm{MgCl}_{2}$, the activity of $\mathrm{MgO}(s), a_{\mathrm{MgO}(s)}$, in the system must be reduced to a low level. In a previous study, the $a_{\mathrm{MgO}(s)}$ was decreased and maintained at a low level via the formation of yttrium oxychloride $(\mathrm{YOCl})\left(\mathrm{O}_{\text {in } \mathrm{Ti}}+\mathrm{Mg}+\mathrm{YCl}_{3} \rightarrow \mathrm{YOCl}+\mathrm{MgCl}_{2}\right)$ in $\mathrm{MgCl}_{2}-\mathrm{YCl}_{3}$ molten salt at $1200-1300 \mathrm{~K}$, and the $\mathrm{O}$ concentration in Ti was decreased to below $1000 \mathrm{mass}$ ppm $\mathrm{O}$ by $\mathrm{Mg}$ $[15]$

Ho is a lanthanide and is commonly known as one of rare earth metals (REMs). It is usually found in minerals such as monazite ((Ce, Y, La, Th) $\left.\mathrm{PO}_{4}\right)$ comprising approximately $65-80 \% \mathrm{La}$ and $\mathrm{Ce}, 15-20 \% \mathrm{Nd}$, and $0.035-0.12 \% \mathrm{Ho}^{[16]}$. Ho is currently used in magnets, nuclear reactors, lasers, and metal halide lamps ${ }^{[16-18]}$. Compared with other REMs, Ho still lacks extensive application in various fields ${ }^{[18]}$. With the increase in the production of $\mathrm{Nd}$, which is used for the production of permanent magnets, an oversupply of Ho may occur in the future because it is a by-product of the production of $\mathrm{Nd}$ and other important REMs ${ }^{[16,19-21]}$.

Thus, a new method using $\mathrm{Mg}$ as a deoxidant in molten $\mathrm{MgCl}_{2}-\mathrm{HoCl}_{3}$ was developed, in which the $a_{\mathrm{MgO}}$ was decreased and maintained at a low level via the formation of holmium oxychloride ( $\mathrm{HoOCl})$. The $\mathrm{O}$ content in $\mathrm{Ti}$ was effectively reduced to a level of approximately 1700 mass ppm $\mathrm{O}$ by $\mathrm{Mg}$ when deoxidation was conducted in $\mathrm{MgCl}_{2}-20$ mol\% $\mathrm{HoCl}_{3}$ molten salt ${ }^{[14]}$. More recently, a new deoxidation method that uses a combination of the formation of $\mathrm{HoOCl}$ and the electrochemical deoxidation technique was developed to further decrease the $\mathrm{O}$ concentration of $\mathrm{Ti}^{[22]}$.

In this study, the feasibility of the electrochemical deoxidization process is discussed and an electrochemical cell that deoxidize Ti simultaneously with the recovery of $\mathrm{HoOCl}$ is proposed. 


\section{Electrochemical deoxidation mechanism}

The $\mathrm{O}$ concentration in $\beta$-Ti cannot be reduced to less than 19300 mass ppm $\mathrm{O}$ by $\mathrm{Mg}$ at $1173 \mathrm{~K}\left(a_{\mathrm{Mg}}=1, a_{\mathrm{MgO}(s)}=\right.$ 1) ${ }^{[14]}$. However, the deoxidation limit can be lowered if the activity of oxide ion, $a_{\mathrm{O}^{2-}}$ (or $a_{\mathrm{MgO}}$ ), in the system can be reduced.

When Ti undergoes cathodic polarization with a $\mathrm{C}$ electrode, metallic $\mathrm{Mg}$ precipitates on the Ti cathode according to Eq. (1) in the molten $\mathrm{MgCl}_{2}-\mathrm{HoCl}_{3}$ during electrolysis and works as a deoxidant because the deposition potential of $\mathrm{Mg}$ is higher than that of $\mathrm{Ho}^{[22]}$.

$$
\left.\mathrm{Mg}^{2+} \text { (in flux }\right)+2 \mathrm{e}^{-}=\mathrm{Mg} \text { (on Ti cathode: in flux) }
$$

The Mg deoxidant reduces the $\mathrm{O}$ dissolved in Ti cathode to $\mathrm{O}^{2-}$, which dissolves in the flux according to Eq. (2).

$$
\left.\left.\mathrm{O}(\text { in Ti cathode })+\mathrm{Mg} \text { (on Ti cathode: in flux })=\mathrm{O}^{2-} \text { (in flux }\right)+\mathrm{Mg}^{2+} \text { (in flux }\right)
$$

The oxide ion, $\mathrm{O}^{2-}$, generated at the cathode, continuously reacts with $\mathrm{Ho}^{3+}$ and $\mathrm{Cl}^{-}$to form $\mathrm{HoOCl}$ according to Eq. (3) in the molten $\mathrm{MgCl}_{2}-\mathrm{HoCl}_{3}$ and decreases $a_{\mathrm{O}^{2-}}$.

$$
\left.\mathrm{O}^{2-}(\text { in flux })+\mathrm{Ho}^{3+} \text { (in flux }\right)+\mathrm{Cl}^{-}(\text {in flux })=\mathrm{HoOCl}(s)
$$

The concentration of $\mathrm{O}^{2-}$ in the molten salt, or $a_{\mathrm{O}^{2-}}$ in the system, can be further decreased by electrochemical oxidation on the $\mathrm{C}$ anode, which forms $\mathrm{CO}_{x}$ gas when the applied voltage at the electrodes is higher than $1.6 \mathrm{~V}$ according to Eq. $(4)^{[22]}$.

$$
\left.x \mathrm{O}^{2-} \text { (in flux }\right)+\mathrm{C}(s)=\mathrm{CO}_{x}(g)+2 x \mathrm{e}^{-}
$$

$\mathrm{Cl}_{2}$ gas evolution occurs at the $\mathrm{C}$ anode according to Eq. (5) in parallel with $\mathrm{CO}_{x}$ effusion when the applied voltages higher than $2.4 \mathrm{~V}^{[22]}$.

$$
2 \mathrm{Cl}^{-} \text {(in flux) }=\mathrm{Cl}_{2}(g)+2 \mathrm{e}^{-}
$$

\section{$\underline{\text { 3. Material and experiments }}$}

The materials used in this study are summarized in Table 1. Figure 3 shows the electrodes and experimental apparatus used. In a typical experiment, approximately $500 \mathrm{~g}$ of reagent-grade anhydrous $\mathrm{MgCl}_{2}$ and approximately 160 g metallic Ho was loaded into a Ti crucible, and then set in a gas-tight stainless-steel chamber. Vacuum drying was subsequently conducted at $673 \mathrm{~K}$ for $48 \mathrm{~h}$, and the $\mathrm{MgCl}_{2}$ was then melted under an $\mathrm{Ar}$ atmosphere.

Approximately $50 \mathrm{~g}$ of silver shot was placed in the chamber to absorb the Mg generated during the displacement reaction and during electrolysis. Approximately $20 \mathrm{~g}$ of Ti sponge was also placed in the chamber as a getter to absorb gaseous impurities ${ }^{[22]}$. 
Table 1 Materials used in electrochemical deoxidation of Ti.

\begin{tabular}{llll}
\hline Materials & Form & Purity & Supplier \\
\hline Ti crucible & $89 \mathrm{~mm}$ in diameter $\times$ & CP-Ti $(>99.5 \%)$ & Shinkinzoku Industry Co., Ltd. \\
& $3 \mathrm{t} \times 335 \mathrm{~L}$ & & \\
Ti electrode & wire with a $3 \mathrm{~mm}$ in & 1200 mass ppm O & Shinkinzoku Industry Co., Ltd. \\
& diameter & $\geq 99.9 \%$ & Nilaco Co., Ltd \\
C electrode & wire with a $6 \mathrm{~mm}$ in & $\geq 99.0 \%$ & Santoku Co., Ltd \\
Ho & diameter & $\geq 97.0 \%$ & Toho Titanium Co., Ltd. \\
Ti & Bulk & & Ijima Kingin Kogyo Co., Ltd \\
$\mathrm{Ag}^{\text {Sponge }}$ & Shot & $\geq 99.9 \%$ & \\
$\mathrm{Anhydrous}_{\mathrm{MgCl}}$ & Flake & $\geq 97.0 \%$ & Wako Pure Chemical Industries, Ltd. \\
\hline
\end{tabular}

The molten salt with a composition of $\mathrm{MgCl}_{2}-20 \mathrm{~mol} \% \mathrm{HoCl}_{3}$ was produced by the following reaction: $\mathrm{Ho}(s)+3 / 2$ $\operatorname{MgCl}_{2}(l)=3 / 2 \mathrm{Mg}(l)+\mathrm{HoCl}_{3}(l)\left(\Delta G_{\mathrm{r}}^{\circ}=-31.6 \mathrm{~kJ}\right.$ at $\left.1173 \mathrm{~K}\right)$. After $\mathrm{MgCl}_{2}$ was melted under an $\mathrm{Ar}$ atmosphere, the $\mathrm{C}$ rod anode was inserted into the molten salt, and pre-electrolysis was conducted to remove metal impurities and gaseous residuals. After pre-electrolysis, electrochemical deoxidation was carried out by applying a fixed voltage of $3.0 \mathrm{~V}$ between the $\mathrm{C}$ anode and Ti cathode ${ }^{[22]}$.

The Ti cathodes were taken out of the molten $\mathrm{MgCl}_{2}$, cooled in a stream of $\mathrm{Ar}$ gas, and then removed from the reaction chamber after the electrochemical deoxidation. The salt adhered to the surface of the Ti sample was removed by leaching with $(1+1)$ acetic acid and $(1+10)$ aqueous $\mathrm{HCl}$ solution, followed by water, alcohol, and acetone, and was thereafter dried ${ }^{[2,22]}$.

Prior to the determination of the $\mathrm{O}$ and $\mathrm{N}$ concentrations in the Ti samples, the Ti samples were chemically polished with a mixture of $\mathrm{HF}: \mathrm{HNO}_{3}: \mathrm{H}_{2} \mathrm{O}$ in a ratio of 1:4:10, and then rinsed with distilled water, alcohol, and acetone before drying. The $\mathrm{O}$ and $\mathrm{N}$ concentrations in the deoxidized Ti samples was analyzed using a TC-600 (LECO Corporation). Each $0.1 \mathrm{~g}$ of Ti sample was melted with approximately $1 \mathrm{~g}$ of high-purity nickel basket (Ni flux 502-344, LECO Corporation) containing $4 \pm 2 \mu \mathrm{g} \mathrm{O}$ in order to evenly extract the O. A standard Ti sample containing $980 \pm 40$ mass ppm $\mathrm{O}$ (Ti pin 501-657, LECO Corporation) was used for calibration in the $\mathrm{O}$ analysis ${ }^{[1,22]}$. 


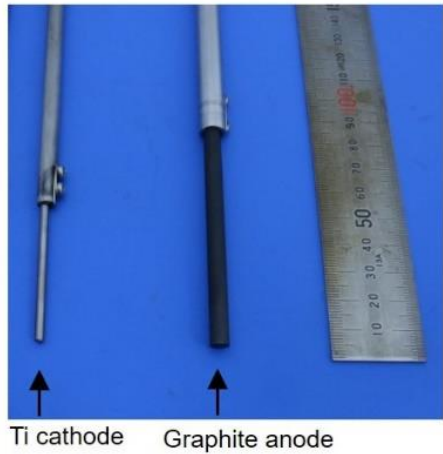

(a)

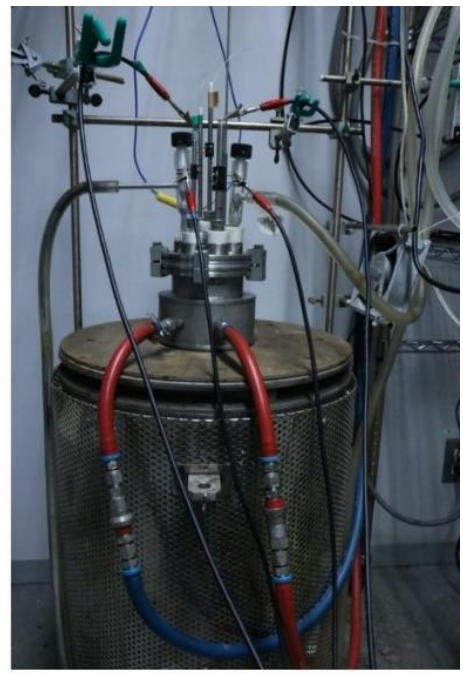

(b)

Fig. 3 Photographs: (a) electrodes; (b) apparatus used for electrochemical deoxidation experiment.

\section{$\underline{\text { 4. Results and discussion }}$}

The experimental conditions and the $\mathrm{O}$ and $\mathrm{N}$ concentrations of the Ti samples before and after electrochemical deoxidation are summarized in Table 2 . The Ti samples (initial O concentrations of approximately 1200 mass ppm O) were deoxidized to approximately 1000 mass ppm $\mathrm{O}$, which is lower than that of thermochemical deoxidation (approximately 1700 mass ppm O). The key feature of this technique is that the $a_{\mathrm{O}^{2-}}$ in the molten $\mathrm{MgCl}_{2}-\mathrm{HoCl}_{3}$ can be maintained at a low-level during electrolysis. It is therefore expected that deoxidation of solid Ti could be conducted efficiently ${ }^{[22]}$.

When managing large amounts of Ti scrap in flux using Mg as a deoxidant, it is difficult to maintain $a_{\mathrm{O}^{2-}}$ (or $a_{\mathrm{MgO}}$ ) in the system at a low level. However, the above-mentioned results indicate that the electrochemical deoxidation process in molten $\mathrm{MgCl}_{2}-\mathrm{HoCl}_{3}$ is favorable for processing large amounts of Ti scrap contaminated with $\mathrm{O}$.

Table 2 Experimental conditions and deoxidation results of electrochemical deoxidation experiments ${ }^{[22]}$.

\begin{tabular}{|c|c|c|c|c|c|c|c|c|}
\hline \multirow[t]{2}{*}{$\begin{array}{l}\text { Exp. } \\
\text { no. }\end{array}$} & \multirow[t]{2}{*}{$\begin{array}{l}\text { Composition of } \\
\text { molten salt }\end{array}$} & \multirow[t]{2}{*}{$\begin{array}{l}\text { Experimental } \\
\text { conditions }^{b}\end{array}$} & \multicolumn{2}{|c|}{$\begin{array}{l}\text { Oxygen } \\
\text { concentration, } C \mathrm{O} \\
(\text { mass ppm O) }\end{array}$} & \multicolumn{2}{|c|}{$\begin{array}{l}\text { Nitrogen } \\
\text { concentration, } C_{\mathrm{N}} \\
(\text { mass ppm } \mathrm{N})\end{array}$} & \multirow{2}{*}{$\begin{array}{l}\text { Maximum } \\
\text { analysis error } \\
\text { of oxygen } \\
\text { concentration } \\
\text { after exp. (\%) }\end{array}$} & \multirow{2}{*}{$\begin{array}{l}\text { Maximum } \\
\text { analysis error } \\
\text { of nitrogen } \\
\text { concentration } \\
\text { after exp. }(\%)\end{array}$} \\
\hline & & & Initial $^{\mathrm{c}}$ & $\begin{array}{l}\text { After } \\
\text { exp. }{ }^{\text {d,e }}\end{array}$ & Initial $^{c}$ & $\begin{array}{l}\text { After } \\
\text { exp. }{ }^{\text {d,e }}\end{array}$ & & \\
\hline $1 \#$ & $\mathrm{MgCl}_{2}-\mathrm{HoCl}_{3}$ & $\begin{array}{l}1173 \mathrm{~K} / 104 \mathrm{ks} \\
3.0 \mathrm{~V} / 2.0 \mathrm{~A}\end{array}$ & 1200 & $\begin{array}{l}(1050), \\
(1070)\end{array}$ & 20 & $\begin{array}{l}(150), \\
(150)\end{array}$ & 6 & 18 \\
\hline $2 \#$ & $\mathrm{MgCl}_{2}-\mathrm{HoCl}_{3}$ & $\begin{array}{l}1173 \mathrm{~K} / 86 \mathrm{ks} \\
3.0 \mathrm{~V} / 2.0 \mathrm{~A}\end{array}$ & 1200 & $\begin{array}{l}1050 \\
(1090)\end{array}$ & 20 & $\begin{array}{l}(150), \\
(150)\end{array}$ & 6 & 18 \\
\hline
\end{tabular}

a: $\mathrm{MgCl}_{2}-20 \mathrm{~mol}_{0} \mathrm{HoCl}_{3}$ (Total salt is about $660 \mathrm{~g}$ in a typical experiment.)

b: Average value of the applied current is noted.

c: Average value of analyzed initial oxygen content is noted. 
$\mathrm{d}$ : Value in a parenthesis includes a lot of uncertainty (out of the calibration line)

e: Representative analytical conditions:

Standard sample: Ti pin $\sim 0.1$ g, $470 \pm 30$ mass ppm O, $70 \pm 20$ mass ppm N, part number: $501-653$

Standard sample: Ti pin $\sim 0.1 \mathrm{~g}, 980 \pm 40$ mass ppm O, $130 \pm 20$ mass ppm N, part number: $501-657$

Ni flux: $\sim 1.0 \mathrm{~g}, 4 \pm 2 \mu \mathrm{g} \mathrm{O}, 0.0 \pm 0.0 \mu \mathrm{g} \mathrm{N}$, part number: 502-344.

Based upon these results, an electrochemical cell which deoxidize Ti scrap or Ti powders and recover HoOCl simultaneously in molten $\mathrm{MgCl}_{2}-\mathrm{HoCl}_{3}$ is designed and illustrated in Fig. 4. Notably, the HoOCl generated in the deoxidation process can be recovered simultaneously with the deoxidation of Ti by the following reaction: $\mathrm{HoOCl}(s)+$ $1 / x \mathrm{C}(s)=\mathrm{Ho}^{3+}+\mathrm{Cl}^{-}+1 / x \mathrm{CO}_{x}(g)+2 \mathrm{e}^{-}$. Therefore, the authors believe that this process will become an efficient and environmentally sound process for Ti recycling.

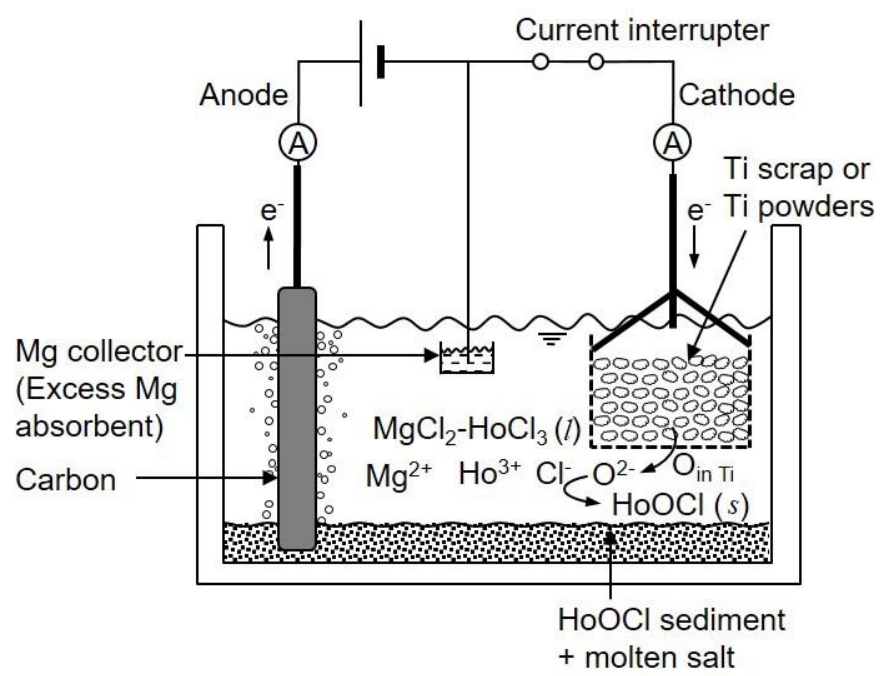

Fig. 4 Electrochemical deoxidation of $\mathrm{Ti}$ in $\mathrm{MgCl}_{2}-\mathrm{HoCl}_{3}$ molten salt.

\section{Conclusion}

In this study, a feasible technique for removing dissolved $\mathrm{O}$ directly from solid Ti by electrochemical deoxidation in $\mathrm{MgCl}_{2}-\mathrm{HoCl}_{3}$ molten salt is discussed. It was confirmed that Ti with an $\mathrm{O}$ concentration of approximately 1000 mass ppm $\mathrm{O}$ is obtained with the applied electrolysis voltage $3.0 \mathrm{~V}$ at $1173 \mathrm{~K}$. According to the experimental results, an electrochemical cell that deoxidize $\mathrm{Ti}$ scrap or $\mathrm{Ti}$ powders simultaneously with the recovery of $\mathrm{HoOCl}$ in molten $\mathrm{MgCl}_{2}-\mathrm{HoCl}_{3}$ is proposed. Using the new deoxidation process proposed in this study, $\mathrm{O}$ in Ti scrap can be efficiently reduced in an environmentally sound manner.

\section{Acknowledgements}

The authors are grateful to Mr. Chenyi Zheng, Mr. Akihiro Iizuka and Mr. Takara Tanaka at The University of Tokyo for their helpful suggestions. This work was financially supported by the Japan Society for the Promotion of Science (JSPS) through a Grant-in-Aid for Scientific Research (S) (KAKENHI Grant No. 26220910 and Grant No. 19H05623). One of 
the authors (L.X. Kong), who is an associate professor in the Faculty of Metallurgical and Energy Engineering, Kunming University of Science and Technology, and also a postdoctoral research fellow in the Institute of Industrial Science, The University of Tokyo, wish to thank the China Scholarship Council (CSC No. 201708530005), the National Natural Science Foundation of China (Grant No. 21968013) and the High-level Talent Platform Construction Program of Kunming University of Science and Technology (Grant No. KKKP201752023) for providing financial support during this research.

\section{References}

[1] O. Takeda, T.H. Okabe, JOM, 71 (6) (2019) 1981-1990.

[2] C.Y. Zheng, T. Ouchi, L.X. Kong, Y. Taninouchi, T.H. Okabe, Metall. Mater. Trans. B, 50 (4) (2019) 1652-1661.

[3] M. Yan, W. Xu, M. S. Dargusch, H. P. Tang, M. Brandt, M. Qian, Powder Metall., 57 (4) (2014) 251-257.

[4] K. Ono and S. Miyazaki, J. Jpn. Inst. Met., 49 (10) (1985) 871-875 (in Japanese).

[5] J.L. Murray, H.A. Wriedt, J. Phase Equilib., 8 (1987) 148-165.

[6] T.B. Massalski, Binary Alloy Phase Diagrams, 2nd ed., ASM International, Materials Park, OH, 1990.

[7] T.H. Okabe, C.Y. Zheng, Y. Taninouchi, Metall. Mater. Trans. B, 49 (3) (2018) 1056-1066.

[8] K.A. Gschneidner, Jr, J. Alloy Compd., 193 (1993) 1-6.

[9] T. H. Okabe, R. O. Suzuki, T. Oishi, K. Ono, Mater. Trans., JIM, 32 (5) (1991) 485-488.

[10] T.H. Okabe, T. Oishi, K. Ono, J. Alloy Compd., 184 (1992) 43-56.

[11] T.H. Okabe, M. Nakamura, T. Oishi, K. Ono, Metall. Trans. B, 24 (3) (1993) 449-455.

[12] J.-M. Oh, K.-M. Roh, J.-W. Lim, Int. J. Hydrogen Energ., 41 (2016) 23033-23041.

[13] Y. Zhang, Z.Z. Fang, P. Sun, T.Y. Zhang, Y. Xia, C.S. Zhou, Z. Huang, J. Am. Chem. Soc., 138 (2016) 6916-6919.

[14] L.X. Kong, T. Ouchi, T.H.Okabe, Mater. Trans., JIM, 60 (9) (2019) 2059-2068.

[15] C.Y. Zheng, T. Ouchi, A. Iizuka, Y. Taninouchi, T.H. Okabe, Metall. Mater. Trans. B, 50 (2) (2019) 622-631.

[16] N. Krishnamurthy and C.K. Gupta, Extractive Metallurgy of Rare Earths, Boca Raton: CRC Press, Taylor \& Francis Group, 2016.

[17] N. Haque, A. Hughes, S. Lim, C. Vernon, Resources, 3 (2014) 614-635.

[18] Y. Gu, Rare Earth Information, 11 (2005) 2930 (in Chinese).

[19] S.M. Pang, S.H. Yan, Z.A. Li, D.H. Cheng, L.H. Xu, B. Zhao, Chin. J. Rare Met., 35 (3) (2011) $440-450$ (in Chinese).

[20] Rare Earths: Global Industry, Markets and Outlook to 2026, 16th Edition, 2016, Roskill Information Services, London, UK, 2016.

[21] F. Habashi, Can. Metall. Quart., 52 (3) (2013) 224-233.

[22] L.X. Kong, T. Ouchi, T.H. Okabe, J. Electrochem. Soc., (2019), in print. 